International Journal of Social Science and Economic Research

ISSN: 2455-8834

Volume:05, Issue:12 "December 2020"

\title{
FOREIGN DIRECT INVESTMENT IN INDIA: AN OVERVIEW
}

\author{
Dr. Y.Mallikarjuna Rao ${ }^{1}$ and Dr. P.Chengalrayulu ${ }^{2}$ \\ ${ }^{1}$ Vice-Principal \& Head, Department of Commerce, Sri Govindaraja Swamy Arts College, Tirupati- \\ 517501 \\ ${ }^{2}$ Lecturer in Commerce, Department of Commerce, Sri Govindaraja Swamy Arts College, Tirupati- \\ 517501
}

DOI: 10.46609/IJSSER.2020.v05i12.010 URL: https://doi.org/10.46609/IJSSER.2020.v05i12.010

\begin{abstract}
The present paper has made an attempt to analyze the growth and development of FDI inflow in India; to exhibit the sector/ year-wise FDI's equity inflows into India; to analyze the country wise approvals of FDI inflows to India and to identify the problems relating to low inflow of FDI in India. The secondary data was collected from various journals, magazines, and websites particularly from the websites of the Department of Industrial Policy \& Promotion, Ministry of Commerce and Industry for a sizable period of ten years from 2010-11 to 2019-20. Statistical and mathematical tools like percentages, ratios and the like are applied to analyze data and to draw noteworthy inferences. This paper revealed that the highest FDI is coming from Singapore followed by Mauritius, Netherlands, USA, Japan, Cayman Islands and the lowest was occupied Belgium and followed by UK Virgin Islands, China, Luxembourg and Cyprus. The highest share of Manufacturing Sector was 22.79 per cent in Foreign Direct Investment inflows into India and the lowest share of others sector was 0.60 per cent, followed by Mining, Real Estate Activities and Education and Research \& Development having 0.67 per cent, 0.73 per cent and 1.15 per cent respectively. It is suggested that the government should provide additional incentives to foreign investors to invest in states where the level of FDI inflows is quite low. It is concluded that FDI is always helps to create employment in the country and also support the small scale industries also and helps country to put an impression on the world wide level through liberalization and globalization.
\end{abstract}

Keywords:_Foreign Direct Investment, Economic growth, Balance of Payment, Reserve Bank of India, Double Taxation

INTRODUCTION 


\section{International Journal of Social Science and Economic Research}

ISSN: $2455-8834$

Volume:05, Issue:12 "December 2020"

Foreign Direct Investment (FDI) has helped India to attain financial stability and economic growth in different sectors. After liberalization of trade policies in India, there has been a positive GDP growth rate in Indian economy. Foreign direct investment helps in developing the economy by generating employment to the unemployed, revenues to the Government in the form of tax and incomes, development of infrastructure, helping establish backward and forward linkages to the domestic firms for meeting the requirements of raw materials, tools, business infrastructure, and acts as supporter for financial system. FDI brings better technology and management, marketing networks and offers competition, the latter helping Indian companies improve, quite apart from being good for consumers. After independence, FDI attracted the attention of the policy makers for acquiring advanced technology and to mobilize foreign exchange resources. In order to boost the FDI inflows into India, the Indian government is allowing frequent equity participation of foreign enterprises by providing many incentives such as tax concessions, simplification of licensing procedures and de-reserving some industries like drugs, fertilizers, aluminum and the like because of significant outflow of foreign reserves in the form of remittances of dividends, profits, royalties and the like. If it is an open economy role of foreign capital is high. Since the under-developed countries lack capital, certainly the foreign capital will make a dent in the process of economic development of that country. Alongside opening up of the FDI regime, steps were taken to allow foreign portfolio investments into the Indian stock market through the mechanism of foreign institutional investors. The objective was not only to facilitate non-debt creating foreign capital inflows but also to develop the stock market in India, lower the cost of capital for Indian enterprises and indirectly improve corporate governance structures. On their part, large Indian companies have been allowed to raise capital directly from international capital markets through commercial borrowings and depository receipts having underlying Indian equity. Thus the country adopted a two-pronged strategy: one to attract FDI which is associated with multiple attendant benefits of technology, access to export markets, skills, management techniques, and the like, and to encourage portfolio capital flows which ease the financing constraints of Indian enterprises.

\section{REVIEW OF LITERATURE}

Sharma Reetu and Khurana Nikita (2013) in their study on the sector-wise distribution of FDI inflow to know about which has concerned with the chief share, used a data from 1991-92 to 2011-2012 (post-liberalization period). This paper also discusses the various problems about the foreign direct investment and suggests the some recommendations for the same. In this study found that, Indian economy is mostly based on agriculture. So, there is a most important scope of agriculture services. Therefore, the foreign direct investment in this sector should be encouraged.

Abhishek Vijaykumar Vyas (2015) has examined that FDI in India has a significant role in the economic growth and development of India. FDI in India to various sectors can attain sustained 


\section{International Journal of Social Science and Economic Research}

ISSN: $2455-8834$

Volume:05, Issue:12 "December 2020"

economic growth and development through creation of job, expansion of existing manufacturing industries. The inflow of FDI in service sectors and construction and development sector, from April 2000 to June 2015 attained substantial sustained economic growth and development through creation of jobs in India. The study concluded that Mauritius emerged as the most dominant source of FDI contributing. It is because the India has Double Taxation Avoidance Agreement (DTAA) with Mauritius and most of the foreign countries like to invest in service sector. Computer, software \& hardware and drugs \& pharmaceutical sector were the other sectors to which attention was shown by foreign direct investment. Indian service sector is generating the proper employment options for skilled worker with high perks. FDI is always helps to create employment in the country and also support the small scale industries also and helps country to put an impression on the world wide level through liberalization and globalization.

Singh, S. (2019) stated in his paper Indian economy is one of the top emerging markets of the world. Five year ago it was considered as part of the fragile, but no longer. Since 2014, it has emerged as of the top foreign destination in the world with a significant rise in FDI. India has become one of the most attractive emerging markets globally. The gross FDI received from April 2000 to June 2018 is US\$ 563320 million. This flow of fund over the year helped the country in advancement of technology, skill up-gradation, employment generation, better infrastructure and management.

Deepak Kumar Adhana \& Neelam Gulati (2019) in their article entitled "An Analysis of Foreign Direct Investment Inflows in India", the present study has focused on the trends of FDI Flow in India during 2000-01 to 2017-18. The study also highlights country wise approvals of FDI inflows to India and the FDI inflows in different sector for the period April 2000 to March 2018. This paper shows that Mauritius has the highest foreign investor in India with 34\%. After Mauritius, Singapore and Japan invest the highest FDI in India with 18\% and 7\% respectively. U.K. also gets $4^{\text {th }}$ position with $7 \%$ FDI in India. The Service sector has the highest FDI Equity inflow 18\%, followed by Computer Software and Hardware, Telecommunication, Construction development and Automobile Industry sector having 8\%, 8\%, 7\%, and 5\% respectively. It is concluded that the difference is significant and leads to conclusion that other sources of Investment rather than Mergers and Acquisitions are least effective and still efforts are require for attracting foreign Investors.

\section{OBJECTIVES OF THE PRESENT PAPER}

The present paper is prepared keeping the following objectives in view.

To analyze the growth and development of FDI inflow in India; 


\section{International Journal of Social Science and Economic Research}

ISSN: $2455-8834$

Volume:05, Issue:12 "December 2020"

To exhibit the sector/ year-wise FDI's equity inflows into India;

To analyze the country wise approvals of FDI inflows to India and

To identify the problems relating to low inflow of FDI in India

\section{METHODOLOGY}

This research is a descriptive study in nature. The secondary data was collected from various journals, magazines, and websites particularly from the websites of the Department of Industrial Policy \& Promotion, Ministry of Commerce and Industry for a sizable period of ten years from 2010-11 to 2019-20. Statistical and mathematical tools like percentages, ratios and the like are applied to analyze data and to draw noteworthy inferences.

\section{ADVANTAGES OF FOREIGN DIRECT INVESTMENT}

The following are the major advantages of foreign Direct Investment (FDI) in India;

$>$ FDI decreases the production cost of goods and services in the host country. Elimination of transaction and transporting cost between host and guest country is possible under FDI.

$>$ FDI plays an important role in the job creation and conservation of local natural resources in the host country.

$>$ Balance of payment status of host country turns into cheering position. FDI increases the industrial productivity of host country.

$>$ FDI improves the GDP rate of host country. It is a symptom of healthy economy. Better GDP rate improves living standards of people in the host country.

$>$ FDI enhances the competition at global level. FDI inflow develops the efficiency and sustains the growth rate of host country.

$>$ State-wise industrial development of the host country can be possible through FDI.

$>$ FDI creates broad opportunities in the traffic of goods and services in the host country. Products of finer quality are manufactured by various industries in the host country. It provides fine status in international trade.

FDI helps in upgrading the existing old working process into a developed process in the host country. Developing countries can make use of advanced technology in industrial and IT sector by inviting FDI.

$>$ Foreign firms invest large amounts in joint ventures of host country. For occupying better market position in the host country they spent large amount on quality and distribution of product. FDI increases the level of competition in the host country. It will result in the 
production of fine quality of products and services at economical prices and are easily available at urban and rural areas in the host country.

FDI also ensures a number of employment opportunities by backing in the creation of industrial units in various corners of the host country. Equilibrium in the economic development of various states of the host country can be possible through FDI.

$>$ FDI has given an inducement to small and domestic producers. They become efficient to compete in their local and outside markets. It will result in enhancing economic growth.

$>$ FDI can formulate large supply of products and services by helping create advanced infrastructure and by introducing technology in the host country.

\section{YEAR-WISE FDI EQUITY INFLOWS INTO INDIA}

Government of India has been in the receipt of FDI. The quantum of FDI received by the Government of India over different years from 2011-12 to 2019-20 are presented in the table 1;

Table 1: Year-wise FDI Equity Inflows into India over a period from 2010-11 to 2019-20

\begin{tabular}{|c|c|c|}
\hline Year & $\begin{array}{c}\text { FDI Inflows } \\
\text { into India } \\
\text { (In US \$ million) }\end{array}$ & $\begin{array}{c}\text { (FDI growth in percentage } \\
\text { terms in US \$) }\end{array}$ \\
\hline $2010-11$ & 34,847 & $34 \%$ \\
\hline $2011-12$ & 46,556 & $-26 \%$ \\
\hline $2012-13$ & 34,298 & $5 \%$ \\
\hline $2013-14$ & 36,046 & $25 \%$ \\
\hline $2014-15$ & 45,148 & $8 \%$ \\
\hline $2015-16$ & 55,559 & $1 \%$ \\
\hline $2016-17$ & 60,220 & $2 \%$ \\
\hline $2017-18$ & 60,974 & $18 \%$ \\
\hline $2018-19$ & 62,001 & - \\
\hline $2019-20$ (P) & 73,455 & \\
\hline Cumulative Total (from & $\mathbf{5 , 0 9 , 1 0 4}$ & \\
\hline $2010-11$ to 2019-20) & & \\
\hline Note: P-Provisiona & & \\
\hline
\end{tabular}

Note: P-Provisional

Source: Reserve Bank of India (RBI), Annual Reports from 2010-11 to 2019-20 and DIPP Reports 
International Journal of Social Science and Economic Research

ISSN: 2455-8834

Volume:05, Issue:12 "December 2020"

Table 1 shows FDI inflows into Indian economy over a period from 2010-11 to 2019-20. The FDI received in India was US \$34,847 Million in 2010-11 and has increased to US \$ 46,556 Million in 2011-12. The FDI inflows into India in 2012-13 and 2013-14 suddenly decreased. But in 2014-15 it was US \$ 45,148 Million and increased to US \$73,455 Million in 2019-20. The cumulative FDI inflows in India was US \$ 5,09,104 Million from 2010-11 to 2019-20. The highest FDI was received in 2019-20 (US \$73,455 Million). The lowest FDI was received in 2012-13 (US \$ 34,298 Million).

The growth in percentage terms in the FDI inflow was the highest in the year 2011-12 (34 per cent). It was very minimal in 2012-13, 2017-18, 2018-19, 2013-14 and 2016-17 because the growth in FDI was -26 per cent, 1 per cent, 2 per cent, 5 per cent and 8 per cent respectively. The second highest growth rate of inflow of FDI in India was in the year 2014-15 (25 per cent) and the third highest growth rate of inflow of FDI in India was in the year 2015-16 (23 per cent). Negative growth rate in the inflow of FDI was observed in 2012-13 during the period under consideration. The growth in the FDI inflow into India in 2011-12 was tremendous.

\section{COUNTRY-WISE INVESTING FDI EQUITY INFLOWS INTO INDIA}

The country wise investing through FDI equity inflows in India from 2015-16 to 2019-20 are presented in table 2;

Table 2: FDI Equity Inflows of Investing Countries into India from 2015-16 to 2019-20

(US\$ in Million)

\begin{tabular}{|l|l|r|r|r|r|r|r|}
\hline $\begin{array}{l}\text { Sl. } \\
\text { No. }\end{array}$ & Country & $\mathbf{2 0 1 5 - 1 6}$ & $\mathbf{2 0 1 6 - 1 7}$ & $\mathbf{2 0 1 7 - 1 8}$ & $\mathbf{2 0 1 8 - 1 9}$ & $\mathbf{2 0 1 9 - 2 0}$ & $\begin{array}{l}\text { Total FDI } \\
\text { Inflows }\end{array}$ \\
\hline 1 & Singapore & 12,479 & 6,529 & 9,273 & 14,632 & 12,612 & $\mathbf{5 5 , 5 2 5}$ \\
\hline 2 & Mauritius & 7,452 & 13,383 & 13,415 & 6,570 & 7,498 & $\mathbf{4 8 , 3 1 8}$ \\
\hline 3 & Netherlands & 2,330 & 3,234 & 2,677 & 2,519 & 5,295 & $\mathbf{1 6 , 0 5 5}$ \\
\hline 4 & Cayman Islands & 440 & 49 & 1,140 & 863 & 3,496 & $\mathbf{5 , 9 8 8}$ \\
\hline 5 & U.S.A. & 4,124 & 2,138 & 1,973 & 2,823 & 3,401 & $\mathbf{1 4 , 4 5 9}$ \\
\hline 6 & Japan & 1,818 & 4,237 & 1,313 & 2,745 & 2,308 & $\mathbf{1 2 , 4 2 1}$ \\
\hline 7 & France & 392 & 487 & 403 & 375 & 1,167 & $\mathbf{2 , 8 2 4}$ \\
\hline 8 & United Kingdom & 842 & 1,302 & 716 & 1,211 & 1,125 & $\mathbf{5 , 1 9 6}$ \\
\hline 9 & South Korea & 241 & 466 & 293 & 982 & 777 & $\mathbf{2 , 7 5 9}$ \\
\hline 10 & Hongkong & 344 & 134 & 1,044 & 598 & 678 & $\mathbf{2 , 7 9 8}$ \\
\hline 11 & Cyprus & 488 & 282 & 290 & 161 & 657 & $\mathbf{1 , 8 7 8}$ \\
\hline 12 & Germany & 927 & 845 & 1,095 & 817 & 443 & $\mathbf{4 , 1 2 7}$ \\
\hline 13 & Belgium & 57 & 172 & 213 & 57 & 388 & $\mathbf{8 8 7}$ \\
\hline 14 & U.A.E. & 961 & 645 & 408 & 853 & 323 & $\mathbf{3 , 1 9 0}$ \\
\hline 15 & Luxembourg & 784 & 99 & 243 & 251 & 252 & $\mathbf{1 , 6 2 9}$ \\
\hline
\end{tabular}


International Journal of Social Science and Economic Research

ISSN: $2455-8834$

Volume:05, Issue:12 "December 2020"

\begin{tabular}{|l|l|r|r|r|r|r|r|}
\hline 16 & UK Virgin Islands & 203 & 212 & 22 & 290 & 251 & $\mathbf{9 7 8}$ \\
\hline 17 & China & 461 & 198 & 350 & 229 & 162 & $\mathbf{1 , 4 0 0}$ \\
\hline 18 & Others & 1,725 & 1,905 & 2,498 & 2,769 & 1,796 & $\mathbf{1 0 , 6 9 3}$ \\
\hline \multicolumn{2}{|c|}{ Total } & $\mathbf{3 6 , 0 6 8}$ & $\mathbf{3 6 , 3 1 7}$ & $\mathbf{3 7 , 3 6 6}$ & $\mathbf{3 8 , 7 4 5}$ & $\mathbf{4 2 , 6 2 9}$ & $\mathbf{1 , 9 1 , 1 2 5}$ \\
\hline
\end{tabular}

Source: Reserve Bank of India (RBI), Annual Reports from 2015-16 to 2019-20 and DIPP Reports

Table 2 depicts the FDI equity inflows from investing countries into India from 2015-16 to 201920. The total FDI inflows in India have been increased from US \$36,068 Million in 2015-16 to US $\$ 42,629$ Million in 2019-20. The total FDI which came to India from the highest countries over the said period is US $\$ 1,91,125$ Million. Out of this US $\$ 55,525$ Million are coming from Singapore has occupied has number one position in lending FDI to India followed by Mauritius, Netherlands, USA, Japan, Cayman Islands, United Kingdom, Germany, U.A.E, France, Hongkong and South Korea. The lowest rank was occupied Belgium and followed by UK Virgin Islands, China, Luxembourg and Cyprus.

From the foregoing analysis one can infer that the highest FDI is coming from Singapore followed by Mauritius, Netherlands, USA, Japan, Cayman Islands and the lowest was occupied Belgium and followed by UK Virgin Islands, China, Luxembourg and Cyprus. The government of India shall convince the countries which are lending low amount of FDI to lend sizable amount. The government shall also motivate the countries which are lending medium sized FDI to India to enhance their size to the maximum extent possible at reasonable rates of interest.

\section{SECTOR-WISE FOREIGN DIRECT INVESTMENT IN INDIA}

Statistical information pertaining to the different sectors which are in the receipt of FDI is presented in the table 3 given here under.

Table 3: Sector / Year-wise FDI Equity Inflows into India from 2015-16 to 2019-20

(US\$ in Million)

\begin{tabular}{|l|c|c|c|c|c|c|c|}
\hline \multicolumn{1}{|c|}{ Source/ Industry } & $\begin{array}{c}\mathbf{2 0 1 5 -} \\
\mathbf{1 6}\end{array}$ & $\begin{array}{c}\mathbf{2 0 1 6 -} \\
\mathbf{1 7}\end{array}$ & $\begin{array}{c}\mathbf{2 0 1 7 -} \\
\mathbf{1 8}\end{array}$ & $\begin{array}{c}\mathbf{2 0 1 8} \\
\mathbf{1 9}\end{array}$ & $\begin{array}{c}\mathbf{2 0 1 9 -} \\
\mathbf{2 0} \mathbf{P}\end{array}$ & $\begin{array}{c}\text { Total } \\
\text { FDI Inflows }\end{array}$ & $\begin{array}{c}\text { Share of FDI } \\
\text { Inflows } \\
(\mathbf{\%})\end{array}$ \\
\hline Manufacturing & 8,439 & 11,972 & 7,066 & 7,919 & 8,153 & $\mathbf{4 3 , 5 4 9}$ & $\mathbf{2 2 . 7 9}$ \\
\hline $\begin{array}{l}\text { Communication } \\
\text { Services }\end{array}$ & 2,638 & 5,876 & 8,809 & 5,365 & 6,838 & $\mathbf{2 9 , 5 2 6}$ & $\mathbf{1 5 . 4 5}$ \\
\hline $\begin{array}{l}\text { Retail \& Wholesale } \\
\text { Trade }\end{array}$ & 3,998 & 2,772 & 4,478 & 4,311 & 4,914 & $\mathbf{2 0 , 4 7 3}$ & $\mathbf{1 0 . 7 1}$ \\
\hline Financial Services & 3,547 & 3,732 & 4,070 & 6,372 & 4,326 & $\mathbf{2 2 , 0 4 7}$ & $\mathbf{1 1 . 5 3}$ \\
\hline Computer Services & 4,319 & 1,937 & 3,173 & 3,453 & 4,104 & $\mathbf{1 6 , 9 8 6}$ & $\mathbf{8 . 8 9}$ \\
\hline Business services & 3,031 & 2,684 & 3,005 & 2,597 & 3,684 & $\mathbf{1 5 , 0 0 1}$ & $\mathbf{7 . 8 5}$ \\
\hline Restaurants and Hotels & 889 & 430 & 452 & 749 & 2,546 & $\mathbf{5 , 0 6 6}$ & $\mathbf{2 . 6 5}$ \\
\hline
\end{tabular}


International Journal of Social Science and Economic Research

ISSN: 2455-8834

Volume:05, Issue:12 "December 2020"

\begin{tabular}{|l|c|c|c|c|c|c|c|}
\hline Transport & 1,363 & 891 & 1,267 & 1,019 & 2,333 & $\mathbf{6 , 8 7 3}$ & $\mathbf{3 . 6 0}$ \\
\hline Construction & 4,141 & 1,564 & 1,281 & 2,009 & 1,937 & $\mathbf{1 0 , 9 3 2}$ & $\mathbf{5 . 7 2}$ \\
\hline $\begin{array}{l}\text { Electricity \& Other energy } \\
\text { Generation, } \\
\text { Distribution \& Transmission }\end{array}$ & 1,364 & 1,722 & 1,870 & 2,427 & 1,906 & $\mathbf{9 , 2 8 9}$ & $\mathbf{4 . 8 6}$ \\
\hline Real Estate Activities & 112 & 105 & 405 & 213 & 564 & $\mathbf{1 , 3 9 9}$ & $\mathbf{0 . 7 3}$ \\
\hline $\begin{array}{l}\text { Education, Research \& } \\
\text { Development }\end{array}$ & 394 & 205 & 347 & 736 & 528 & $\mathbf{2 , 2 1 0}$ & $\mathbf{1 . 1 5}$ \\
\hline Miscellaneous Services & 1,022 & 1,816 & 835 & 1,226 & 443 & $\mathbf{5 , 3 4 2}$ & $\mathbf{2 . 8 0}$ \\
\hline Mining & 596 & 141 & 82 & 247 & 216 & $\mathbf{1 , 2 8 2}$ & $\mathbf{0 . 6 7}$ \\
\hline Trading & - & - & - & - & - & - & - \\
\hline Others & 215 & 470 & 226 & 102 & 137 & $\mathbf{1 , 1 5 0}$ & $\mathbf{0 . 6 0}$ \\
\hline Total & $\mathbf{3 6 , 0 6 8}$ & $\mathbf{3 6 , 3 1 7}$ & $\mathbf{3 7 , 3 6 6}$ & $\mathbf{3 8 , 7 4 5}$ & $\mathbf{4 2 , 6 2 9}$ & $\mathbf{1 , 9 1 , 1 2 5}$ & $\mathbf{1 0 0 . 0 0}$ \\
\hline
\end{tabular}

Note: P-Provisional

Source: Reserve Bank of India (RBI), Annual Reports from 2015-16 to 2019-20 and DIPP Reports

Table 3 reveals the sector / year-wise FDI equity inflows into India from 2015-16 to 2019-20. It is understood that the highest share in Foreign Direct Investment inflows into India is the services comprising of Manufacturing Sector was 22.79 per cent, followed by Communication Services, Financial Services, Retail \& Wholesale Trade, Computer Services, Business Services, Construction, Electricity \& Other energy Generation, Distribution \& Transmission, Transport, Restaurants \& Hotels and Miscellaneous Services having 15.45 per cent, 11.53 per cent, 10.71 per cent, 8.89 per cent, 7.85 per cent, 5.72 per cent, 4.86 per cent, 3.60 per cent, 2.80 per cent and 2.65 per cent respectively. The lowest share of others sector was 0.60 per cent, followed by Mining, Real Estate Activities and Education and Research \& Development having 0.67 per cent, 0.73 per cent and 1.15 per cent respectively. The trading sector no share in FDI inflows into India from 2015-16 to 2019-20.

From the foregoing analysis one can infer that the highest share of Manufacturing Sector was 22.79 per cent in Foreign Direct Investment inflows into India and the lowest share of others sector was 0.60 per cent, followed by Mining, Real Estate Activities and Education and Research \& Development having 0.67 per cent, 0.73 per cent and 1.15 per cent respectively. The trading sector no share in FDI inflows into India from 2015-16 to 2019-20.

\section{PROBLEMS FOR LOW FDI INFLOW TO INDIA}

India, the largest democratic country with the second largest population in the world, with rule of law and a highly educated English speaking work force, the country is considered as a safe haven for foreign investors. Yet, India seems to be suffering from a host of self-imposed restrictions and problems regarding opening its markets completely too global investors by implementing full scale economic reforms. Some of the major impediments for India's poor performance in the 
International Journal of Social Science and Economic Research

ISSN: 2455-8834

Volume:05, Issue:12 "December 2020"

area of FDI are: political instability, poor infrastructure, confusing tax and tariff policies, Draconian labour laws, well entrenched corruption and governmental regulations.

\section{Lack of adequate infrastructure}

It is cited as a major hurdle for FDI inflows into India. This bottleneck in the form of poor infrastructure discourages foreign investors in investing in India. India's age old and biggest infrastructure problem is the supply of electricity. Power cuts are considered as a common problem and many industries are forced to close their business.

\section{Stringent labour laws}

Large firms in India are not allowed to retrench or layoff any workers, or close down the unit without the permission of the state government. These laws protect the workers and thwart legitimate attempts to restructure business. To retrench unnecessary workers, firms require approval from both employees and state governments-approval that is rarely given. Further, Trade Unions extort huge sums from companies through over-generous voluntary retirement schemes.

\section{Corruption}

Corruption is found in nearly every public service, from defense to distribution of subsidized food to the poor people, to the generation and transmission of electric power. The combination of legal hurdles, lack of institutional reforms, bureaucratic decision-making and the allegations of corruption at the top have turned foreign investors away from India.

\section{Lack of decision making authority with the state governments}

The reform process of liberalizing the economy is concentrated mainly in the Centre and the State Governments are not given much power. In most key infrastructure areas, the central government remains in control. Brazil, China, and Russia are examples where regional governments take the lead in pushing reforms and prompting further actions by the central government.

\section{Limited scale of export processing zones}

India's export processing zones have lacked dynamism because of several reasons, such as their relatively limited scale; the Government's general ambivalence about attracting FDI; the unclear and changing incentive packages attached to the zones; and the power of the central government in the regulation of the zones. India which established its first Export Processing Zone (EPZ) in 
1965 has failed to develop the zones when compared to China which took initiative for establishment only in 1980.

\section{High corporate tax rates}

Corporate tax rates in East Asia are generally in the range of 15 to 30 per cent, compared with a rate of 48 percent for foreign companies in India. High corporate tax rate is definitely a major disincentive to foreign corporate investment in India.

\section{Indecisive government and political instability}

There were too many anomalies on the government side during past two decades and they are still affecting the direct inflow of FDI in India such as mismanagement and oppression by the different company, which affect the image of the country and also deject the prospective investor, who is very much conscious about safety and constant return on their investment.

\section{SUGGESTIONS}

The government should provide additional incentives to foreign investors to invest in states where the level of FDI inflows is quite low.

$>$ Government should ensure the equitable distribution of inflows among low States and must give more freedom to states, so that they can attract inflows at Government must target at attracting specific types of FDI their own level that will be able to generate spillovers effects in the overall economy like investing in human capital, R\&D activities, environmental issues, productive capacity, sectors with high income elasticity of demand.

$>$ The policy makers should focus more on attracting diverse types of FDI and should design policies where foreign investment can be utilized as means of enhancing domestic production, savings, and exports and also as medium of technological learning and diffusion and also in providing access to the Government must exercise strict control over inefficient external market, bureaucracy, red - tapism, and the rampant corruption, so that investor's confidence can be maintained for attracting more FDI inflows to India.

\section{CONCLUSION}

FDI in India has a significant role in the economic growth and development of India. FDI in India to various sectors can attain sustained economic growth and development through creation of jobs, expansion of existing manufacturing industries. So, we can conclude that FDI is always helps to create employment in the country and also support the small scale industries also and helps country to put an impression on the world wide level through liberalization and 
International Journal of Social Science and Economic Research

ISSN: 2455-8834

Volume:05, Issue:12 "December 2020"

globalization. It is reveals that the manufacturing sector accounted for a steeply rising share of FDI stocks in India followed by financial services, construction development, and business services. The money from FDI has allowed India to focus on the areas that needed a boost and economic attention, and address the various problems that continue to challenge the country.

\section{REFERENCES}

1. Sharma R. \& Khurana N. (2013), "Role of Foreign Direct Investment (FDI) in Different Sectors", International Journal of Advances in Management and Economics, Jan.-Feb., Vol. 2, Issue 1, Pp.14-19

2. Singh, S. (2019) "Foreign direct investment inflows in India", Journal of General Management Research, Vol. 6, issue 1, Pp. 41-53.

3. Deepak Kumar Adhana \& Neelam Gulati (2019), “An Analysis of Foreign Direct Investment Inflows in India", International Journal for Research in Engineering Application \& Management (IJREAM), Vol-05, Issue-01, April, Pp.122-132.

4. Singh, Gurmeet and Paul, Justin (2014), "Foreign Direct Investment in India- Trends, Pattern and Linkage" SMART Journal of Business Management Studies, Vol. 10, No.1, Jan -June, Pp 19-29

5. Aggrawal, S., Singla, A., Aggrawal, R. (2012), "Foreign Direct Investment in India", International Journal of Computational Engineering \& Management, Vol.15, Issue 5, Pp.93-105

6. Abhishek Vijaykumar Vyas (2015), "An Analytical Study of FDI in India (2000-2015)", International Journal of Scientific and Research Publications, Vol.05, Issue 10, October, Pp.1-30. 